Research Paper

\title{
Enhanced production of Aspergillus tamarii lipase for recovery of fat from tannery fleshings
}

\author{
A. Dayanandan, S. Hilda Vimala Rani, M. Shanmugavel, \\ A. Gnanamani, G. Suseela Rajakumar \\ Department of Microbiology, Central Leather Research Institute, Tamil Nadu, New Delhi.
}

Submitted: February 8, 2012; Approved: April 4, 2013.

\begin{abstract}
The influence of various oil cakes has been investigated for high level production of lipase using Aspergillus tamarii MTCC 5152. By solid state fermentation in wheat bran containing $2.5 \% \mathrm{w} / \mathrm{w}$ gingili oil cake at $70 \% \mathrm{v} / \mathrm{w}$ moisture content the fungus produced a maximal yield of lipase (758 \pm $3.61 \mathrm{u} / \mathrm{g}$ ) after 5 days of incubation using $2 \% \mathrm{v} / \mathrm{w}$ inoculum containing $10^{6}$ spores $/ \mathrm{mL}$. Wheat bran and gingili oil cake with supplementation of gingili oil $(1.0 \% \mathrm{w} / \mathrm{w})$, glucose $(0.5 \% \mathrm{w} / \mathrm{w})$ and peptone $(0.5 \% \mathrm{w} / \mathrm{w})$ gives an increased enzyme production of $793 \pm 6.56 \mathrm{u} / \mathrm{g}$. The enzyme shows maximum activity at $\mathrm{pH} 7.0$, temperature $50{ }^{\circ} \mathrm{C}$ and was stable between the $\mathrm{pH} 5.0-8.0$ and temperature up to $60{ }^{\circ} \mathrm{C}$. Crude lipase (3\%) applied to tannery fleshing shows $92 \%$ fat solubility. The results demonstrate that fat obtained from tannery fleshing, a by-product of the leather industry has a high potential for biodiesel production and the proteinaceous residue obtained can be used as animal feed.
\end{abstract}

Key words: wheat bran, oil cakes, lipase, tannery fleshing, fat hydrolysis.

\section{Introduction}

Leather industries are facing pollution problem due to generation of solid wastes from the beam house operations. Tannery fleshing is a waste, generated mainly after dehairing of animal hides and skins by the mechanical processes in the form of trimming, fleshing and shaving. These fleshings are rich in proteins and fats and generally just dumped or underutilized. Most of the solid wastes occur in the pre-tanning stages. The general composition of solid waste originating from pre-tanning process consist of natural fats, proteins, blood, water, salt and other wastes and become a source of environmental pollution inspite of these wastes carry a high potential for reutilization. Hide fleshing accounts for $50-60 \%$ of waste generated in the tannery (Colak et al., 2005). The bovine hide fleshing have been reported to contain $80 \%$ water; the protein content of the dry matter was $63 \%$, fat $14 \%$ and ash content $8 \%$ (Kamini et al., 2000). The byproducts obtained from the fleshing may be used as a poultry feed and biofertilizer after recovering the fat using lipase.
Industrial enzymes are used in detergents, laundry and dishwashing agents, leather dehairing and tanning, desizing of textiles, deinking of paper and degreasing of hides and skins (Dayanandan et al., 2003; Headon and Walsh, 1994). The use of enzymes frequently results in many benefits that cannot be obtained by traditional chemical processes, includes quality improvement in products and minimum manufacturing cost, reduced waste generation and lower energy consumption. The enzymatic process can be controlled through various means, such as dose, temperature and time.

Lipases are a unique group of enzymes that catalyze the hydrolysis of fats and oils. Lipids are water-insoluble complex biomolecules and lipases play an important role in the breakdown of these compounds. Microbial lipases are often more useful than enzymes derived from plants or animals because of the high yield, ease of genetic manipulation and production through the rapid growth of microorganisms on inexpensive media. Microbial lipases are also more stable and their production process is more convenient and safer (Harwood, 1989; Wiseman, 1995). The en-

Send correspondence to A. Dayanandan. Microbiology Department, Central Leather Research Institute, Adyar, Chennai 600020 Tamil Nadu, India. E-mail: asdaya17@gmail.com. 
zyme production could be further enhanced by optimization of physiological and biological conditions. Microbial lipases can be produced from bacteria, fungi and yeast by using processes like solid-state (SSF) and submerged fermentation (SmF) methods (Ramachandran et al., 2007; Graminha et al., 2008). Hence, the current study focuses on solid-state fermentation with the combined effects of various oil cakes and wheat bran for enhanced production of lipase and also studies the potential of this enzyme for the recovery of high value fat from fat rich waste tannery fleshing which may find applications in chemical industries and biodiesel production (Colak et al., 2005; Ozgunay et al., 2007).

\section{Materials and Methods}

\section{Materials, microorganism and inoculum}

Analytical grade chemicals of Hi-Media and Merck were used for the present study. Wheat bran, gingili, ground nut, cotton seed and coconut oil cakes were purchased from the local supplier. Aspergillus tamarii MTCC 5152 used in the present work was isolated from soil and maintained on Czapek-Dox's agar medium. Spores from 7 day old cultures raised on Czapek-Dox's agar plates incubated at $28 \pm$ $2{ }^{\circ} \mathrm{C}$ were harvested with sterile distilled water containing $0.1 \%$ Tween- 80 and used as an inoculum after adjusting to the desired spore count using a haemocytometer. Bovine hides fleshing were obtained from a commercial leather processing unit.

\section{SSF and growth conditions}

Erlenmeyer flasks $(250 \mathrm{~mL})$ containing $10 \mathrm{~g}$ of solid substrates were moistened with water $(70 \% \mathrm{v} / \mathrm{w})$ and sterilized at $121^{\circ} \mathrm{C}$ for $15 \mathrm{~min}$. After cooling, the flasks were inoculated with $2 \% \mathrm{v} / \mathrm{w}$ inoculum containing $10^{6}$ spores $/ \mathrm{mL}$. The contents of each flask were mixed thoroughly with a sterile glass rod for uniform distribution of fungal spores in the medium and incubated at $28{ }^{\circ} \mathrm{C}$ for the fungal growth. After the incubation period, the contents from each flask were extracted for lipase enzyme and the enzyme activities were estimated every $24 \mathrm{~h}$ intervals for a period of 7 days.

\section{Extraction and enzyme assay methods}

The moldy wheat bran was thoroughly mixed with $100 \mathrm{~mL}$ of $0.1 \mathrm{M}$ phosphate buffer, $\mathrm{pH} 7.0$ containing $0.1 \%$ Tween- 80 and shaken in an orbital shaker at $28^{\circ} \mathrm{C}$ for $1 \mathrm{~h}$. The contents were then filtered through cheese cloth, combined and centrifuged at $10,000 \mathrm{rpm}$ for $15 \mathrm{~min}$ at $4{ }^{\circ} \mathrm{C}$ in a refrigerated centrifuge (Sigma $3 \mathrm{~K} 30$ ) and used as a crude enzyme extract. Two methods were adopted to assay the lipase activity. Enzyme activity was assayed through alkali titration method with olive oil emulsion as the substrate, using a modified version of the procedure described by Saxena et al. (2003). In brief, the assay mixture consisting $5 \mathrm{~mL}$ of olive oil emulsion, $4 \mathrm{~mL} 0.1 \mathrm{M}$ phosphate buffer
$(\mathrm{pH} 7.0)$ and $1 \mathrm{~mL}$ crude enzyme extract was mixed well and incubated for $20 \mathrm{~min}$ at $37{ }^{\circ} \mathrm{C}$. The reaction was stopped by the addition of $20 \mathrm{~mL}$ of acetone. This mixture was then titrated with $0.05 \mathrm{M} \mathrm{NaOH}$ in the presence of $0.1 \%$ phenolphthalein $(0.1 \mathrm{~mL})$ as the indicator. The titration values were used to calculate lipase activity. One unit of lipase activity is defined as the amount of enzyme required to release $1 \mu \mathrm{mol}$ of fatty acid per minute under the standard assay conditions.

Lipase activity was also assayed by the spectrophotometric method (Kwon and Rhee, 1986). In short $50 \mu \mathrm{L}$ of enzyme extract was added to $5 \mathrm{~mL}$ of olive oil emulsion and incubated for $15 \mathrm{~min}$ at $40{ }^{\circ} \mathrm{C}$. Olive oil emulsion was prepared by mixing $20 \mathrm{~g}$ of olive oil and $100 \mathrm{~mL}$ of $0.1 \mathrm{M}$ phosphate buffer $\mathrm{pH} 7.0$, containing $10 \mathrm{mM} \mathrm{CaCl}_{2}$ and $0.25 \%$ polyvinyl alcohol (PVA) in a Homogenizer (1500 rpm for $30 \mathrm{~min}$ ). The reaction was stopped with $1 \mathrm{~mL}$ of $6 \mathrm{M} \mathrm{HCl}$ and incubated in a boiling water bath for $5 \mathrm{~min}$. The fatty acids released were extracted in $5 \mathrm{~mL}$ of isooctane by vortexing for $15 \mathrm{~min}$. To $2.5 \mathrm{~mL}$ of organic phase, $0.5 \mathrm{~mL}$ of a copper acetate-pyridine solution $(50 \mathrm{~g} / \mathrm{L}, \mathrm{pH} 6.1$ adjusted with pyridine) was added, vortexed for $15 \mathrm{~min}$ and centrifuged at $5000 \mathrm{rpm}$ for $15 \mathrm{~min}$ and the absorbance of the organic phase was monitored at $715 \mathrm{~nm}$. A calibration curve was drawn using oleic acid as a standard. One unit of activity was defined as the amount of the enzyme, which release $1 \mu \mathrm{mol}$ of fatty acid per minute in the assay conditions. The results obtained did not show much difference in the values. The alkali titration method of Saxena et al. (2003) was followed throughout the experiments. The protein content of the crude enzyme extract was analyzed by the method of Lowry et al. (1951).

To study the potential of lipase for tannery fleshing hydrolysis, the crude culture extract as an enzyme source was ultra concentrated to 10 fold concentration using $10 \mathrm{Kda}$ cut off cellulose membrane (Millipore, USA). The ultra concentrated liquid enzyme was acetone precipitated using pre chilled acetone at the ratio $1: 1.2 \mathrm{v} / \mathrm{v}$. The precipitate was collected after centrifugation at 10,000 rpm for $20 \mathrm{~min}$ at $4{ }^{\circ} \mathrm{C}$, lyophilized (Virtis lyophiliser) and used for biochemical characterization.

\section{Optimization of growth parameters for lipase produc- tion by SSF}

The effect of different parameters to optimize lipase production in SSF were studied by varying one parameter at a time and the growth conditions are as described in Section 2.2. The parameters studied were initial moisture content $(40,50,60,70,80$ and $90 \%)$, incubation period ( 24 to $168 \mathrm{~h}$ ), oil cakes (gingili, ground nut, cotton seed and coconut oil cakes), additional nitrogen sources (ammonium nitrate, ammonium sulphate, peptone, sodium nitrate and yeast extract), oil sources (castor oil, olive oil, coconut oil, gingili oil and sunflower oil) and carbohydrate sources (fructose, glucose, glycerol, lactose and xylose). The pa- 
rameters optimized each time were incorporated in subsequent experiments. Lipase activities are expressed in units per gram of dry weight of the fermented substrate.

\section{$\mathrm{pH}$ and temperature related activity and stability of} lipase

To study the potency of lipase to hydrolyze tannery fleshing, the effect of reaction temperature and $\mathrm{pH}$ on lipase activity and its stability at various temperatures and $\mathrm{pH}$ were evaluated. The buffers used were: $0.02 \mathrm{M}$ Sodium acetate buffer ( $\mathrm{pH} 4.0,5.0), 0.02 \mathrm{M}$ Pottassium phosphate buffer ( $\mathrm{pH}$ 6.0), $0.02 \mathrm{M}$ Tris buffer ( $\mathrm{pH} 7.0,8.0), 0.02 \mathrm{M}$ Borate buffer $(\mathrm{pH} 9.0), 0.02 \mathrm{M}$ Borax- $\mathrm{NaOH}$ buffer (pH 10). To determine the effect of $\mathrm{pH}$ and temperature on the stability of lipase, the enzyme was pre-incubated for $30 \mathrm{~min}$ in various buffer solutions at different $\mathrm{pH}$ (5 to 10) and at various temperatures $\left(30\right.$ to $\left.80{ }^{\circ} \mathrm{C}\right)$ and the residual lipaseactivity was assayed under standard assay conditions. For $\mathrm{pH}$ stability, the enzyme was pre-incubated at $30^{\circ} \mathrm{C}$.

\section{Determination of total lipid content of tannery flesh- ing}

The $\mathrm{pH}$ of the limed fleshing was around 12-12.5. To adjust to the required $\mathrm{pH}$, the fleshing was soaked in water for 1.0-2.0 $\mathrm{h}$ with intermittent stirring and adjusted to required $\mathrm{pH}$ level using $2 \mathrm{~N} \mathrm{HCl}$. These fleshings were used for further investigation. The total lipid content of the tannery fleshing was estimated by the modified chloroform/methanol / water extraction method (Bligh and Dyer, 1959).

\section{Determination of total Kjeldahl nitrogen content (TKN)}

Dried fleshing was chemically hydrolyzed using $6 \mathrm{~N}$ $\mathrm{HCl}$ at $110{ }^{\circ} \mathrm{C}$ for $18 \mathrm{~h}$ till the fleshing was completely solubilized. After hydrolysis, the total Kjeldahl nitrogen content (TKN) of the fleshing was estimated by the method of Mckenzie and Wallace (1954). The values of TKN were multiplied by the factor 5.51 to calculate the protein content (Taylor et al., 1997) and the results are expressed in percentage.

\section{Ash content of tannery fleshing}

The total ash content of tannery fleshing was measured by the standard test method ASTM D2617-96. Five grams of dried tannery fleshing were weighed and placed in a clean pre weighed crucible. The crucible was kept in a muffle furnace at $600 \pm 25^{\circ} \mathrm{C}$ for $1 \mathrm{~h}$, cooled in a desiccator and weighed to constant weight. The percentage of the total ash content of the tannery fleshing is: Total ash $(\%)=$ weight of the ash/weight of tannery fleshing $\times 100$.

\section{Fat recovery from tannery fleshing using lipase from} A. tamarii MTCC 5152

A. tamarii MTCC 5152 lipase concentrated by ultrafiltration was used for fat hydrolysis. Ten grams of fleshing were suspended in 3 parts of $0.1 \mathrm{M}$ phosphate buffer, pH 7.0 in Erlenmeyer flasks. Enzyme solution containing $750 \mathrm{u} / \mathrm{mL}$ of lipase activity at different concentrations were taken in the same buffer and added to the fleshing and incubated at $50{ }^{\circ} \mathrm{C}$ for a specific period of time ranging from 1 to $6 \mathrm{~h}$. After the incubation period, the hydrolyzate was filtered through pre-weighed Whatman No.1 filter paper and the supernatant was used for the analysis of fat solubility by using a modified procedure described by Saxena et al. (2003). The protein remained as a residue in the filter paper.

All experiments were done in triplicate and the values presented are the means of three independent determinations.

\section{Results and Discussion}

\section{Effect of initial moisture content on lipase produc- tion}

The initial moisture level of the fermentation media plays a vital role for the optimum production of enzymes (Pandey et al., 2000). In the present investigation, maximum lipase production was obtained in wheat bran containing $2.5 \% \mathrm{w} / \mathrm{w}$ gingily oil cake with $70 \%$ moisture content as growth medium (Figure 1). Increase or reduction of moisture level in this wheat bran-gingerly oil cake medium resulted in lower levels of lipase production. A similar trend was reported by Gutarra et al. (2005) with Penicillium simplicissimum in solid-state fermentation using babassu cake as the basal medium but Mahanta et al. (2008) reported initial moisture content at $50 \%$ of substrate as ideal for lipase production using Jatropha curcas seed cake. Therefore, it is evident that the enzyme production depends on the water holding capacity of the substrate and that it varies in various fermentation media.

\section{Effect of combinations of wheat bran with various oil cakes}

Identification of ideal agro-based oil cakes for lipase production in a solid-state fermentation process depends on the cost and availability of such substrates and thus involves screening of several agro-industrial residues. Pandey et al., 2000. The results in the present study revealed that (Figure 2) maximum lipase activity was found on wheat bran with $2.5 \% \mathrm{w} / \mathrm{w}$ gingili oil cake combination compared to wheat bran containing other oil cakes (coconut, cottonseed, groundnut studied at $0.5-10 \% \mathrm{w} / \mathrm{w}$ ). Ramachandran et al. (2007) indicated that lipase production pattern varied with the type of agro-waste. This could be attributed to the solid material's dual role: supply of nutrients for microbial growth and anchorage for the growing mycelia. Kamini et al. (2000) reported maximum production of lipase by Aspergillus niger strain MTCC2594 by solid-state fermentation using gingili oil cake. 


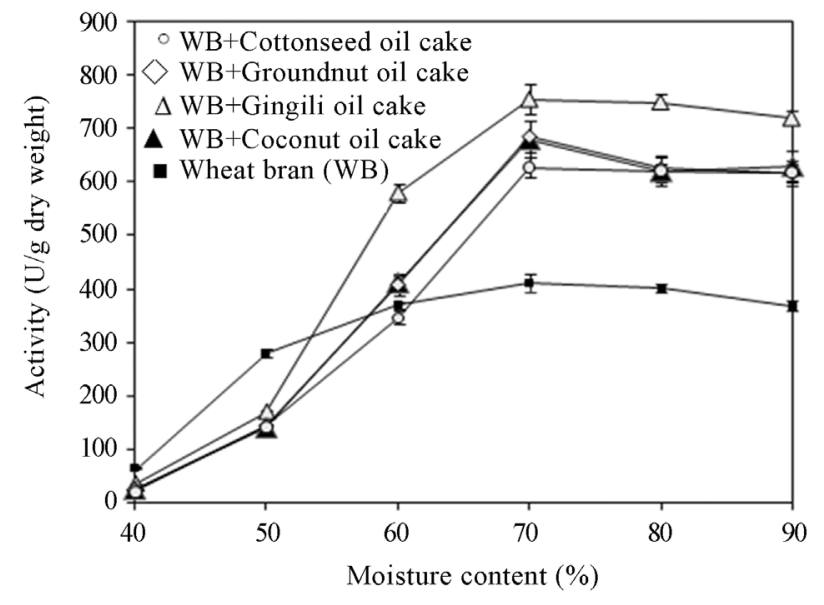

Figure 1 - Effect of initial moisture content on lipase production.

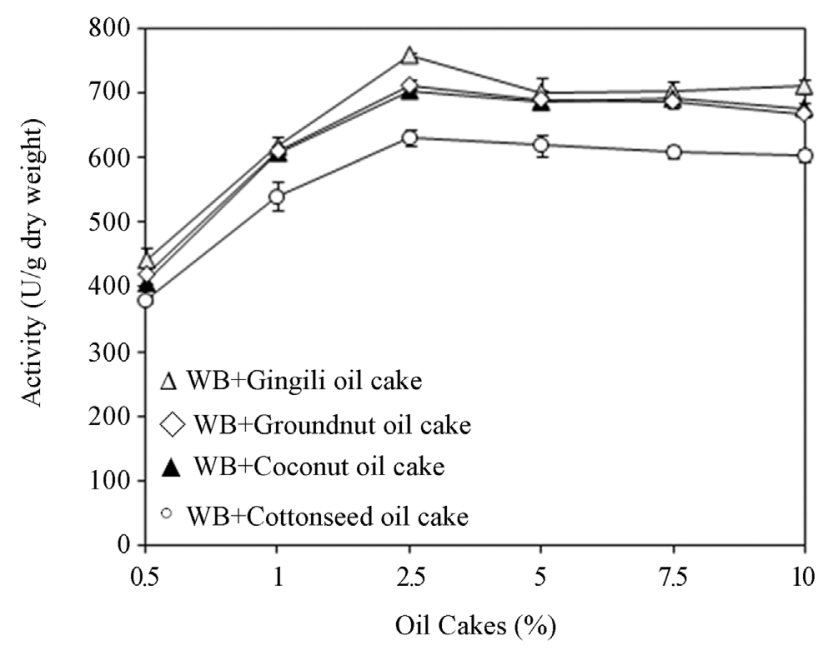

Figure 2 - Effect of oil cakes on lipase production.

\section{Time course on enzyme production}

Lipase production increased with incubation time (Figure 3). Maximum lipase production was obtained with wheat bran containing $2.5 \% \mathrm{w} / \mathrm{w}$ gingili oil cake $(740 \pm$ $17.44 \mathrm{u} / \mathrm{g}$ ) after $120 \mathrm{~h}$. A prolonged incubation time beyond this period did not help to further increase the enzyme yield which might be due to the depletion of nutrients, accumulation of toxic end products and the change in $\mathrm{pH}$ of the medium or loss of moisture. These results are in accordance with the observations made by Mahadik et al. (2002) for lipase production by Aspergillus niger. Several researchers have reported different incubation periods for optimal lipase production by solid state fermentation. Cordova et al. (1998) reported maximum lipase activity by $R$. pullis after $24 \mathrm{~h}$ of incubation using mixture of olive oil cake and sugarcane bagasse as substrates. Benjamin and Pandey (1997) obtained maximum production of lipase by Candida rugosa after 3 days of incubation period.

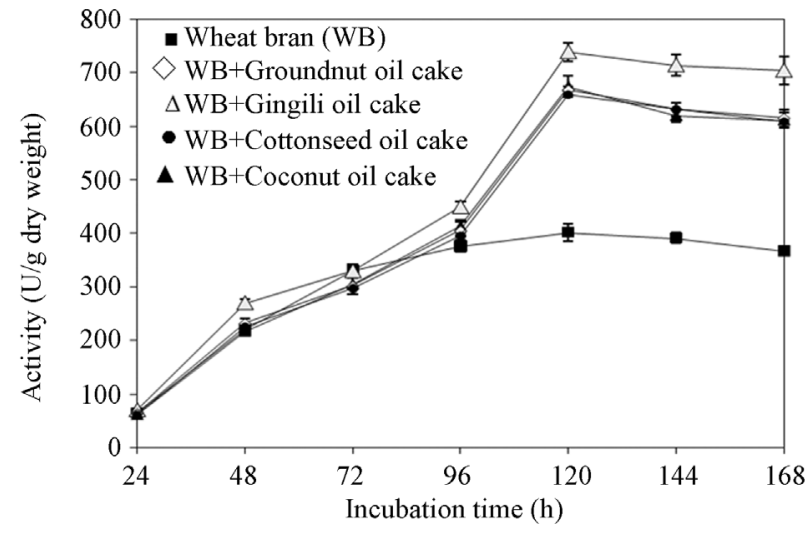

Figure 3 - Effect of incubation time on lipase production.

\section{Effect of additional supplementation of oil, carbohy-} drate and nitrogen sources on lipase production

Results of additional supplementation of oil, nitrogen and carbohydrate sources on enzyme production by $A$. tamarii MTCC 5152 are shown in Table 1. Maximum lipase activity was found $(782 \pm 14.73 \mathrm{u} / \mathrm{g}$ ) when $1 \%$ gingili oil was added to wheat bran containing gingili oil cake. Mladenoska and Dimitrovski (2001) tested several lipids for their effect on lipase production by Geotrichum candidum M 2 and obtained highest lipolytic activity using sunflower oil sediments and sunflower oil. Lima et al. (2003) reported that olive oil induces higher yield of lipase by Penicillium aurantiogriseum.

Among the nitrogen sources used peptone $(0.5 \%)$ showed maximum influence in enhancing the enzyme production $(787 \pm 5.57 \mathrm{u} / \mathrm{g})$. Benjamin and Pandey (1997) reported that urea was found to be the best nitrogen source for lipase production with Candida rugosa. The addition of other nitrogen sources did not show any supportive effect on lipase production.

Regarding the effects of additional carbon sources on enzyme production the results showed that glucose supported maximum production of lipase $(785 \pm 9.64 \mathrm{u} / \mathrm{g})$. The addition of gingili oil $(1.0 \%)$, peptone $(0.5 \%)$ and glucose $(0.5 \%)$ to wheat bran and gingili oil cake in SSF supported enhanced production of lipase (793 $\pm 6.56 \mathrm{u} / \mathrm{g})$. Increasing peptone and glucose to $1 \%$ concentration did not show much variation (data not shown).

\section{Effect of $\mathrm{pH}$ and temperature on activity and stability of lipase}

The $\mathrm{pH}$ profile of crude lipase is displayed in Figure 4. A. tamarii MTCC 5152 lipase shows maximum activity at $\mathrm{pH} 7.0$ and the enzyme was also found to retain $100 \%$ of activity in the same $\mathrm{pH}$. More than $90 \%$ of activity was retained at $\mathrm{pH} 5,6$ and 8 indicating a very little decrease in activity and at $\mathrm{pH} 10.0,72 \%$ of residual activity was found. Interestingly, the present lipase was active even at $\mathrm{pH}$ 
ranges from 5.0 to 8.0. Lipases from Aspergillus niger (Sugihara et al., 1988), Aspergillus terreus (Ghosh et al., 1996) and Rhizopus oligosporous (Ul-Haq et al., 2002) were found to be stable in the $\mathrm{pH}$ ranges 3-10.5, 5.5-10 and

Table 1 - Effect of additional oil, carbohydrate and nitrogen sources on lipase production by $A$. tamarii.

\begin{tabular}{lc}
\hline Sources & Lipase activity $(\mathrm{u} / \mathrm{g})$ \\
\hline Fermentation medium & \\
Wheat bran & $408 \pm 16.64$ \\
Wheat bran + Gingili oil cake & $758 \pm 3.61$ \\
Oil source $(1 \% \mathrm{w} / \mathrm{w})$ & \\
Gingili oil & $782 \pm 14.73$ \\
Castor oil & $763 \pm 8.66$ \\
Coconut oil & $760 \pm 15.39$ \\
Olive oil & $761 \pm 10.15$ \\
Sunflower oil & $756 \pm 17.32$ \\
Nitrogen sources $(0.5 \% \mathrm{w} / \mathrm{w})$ & \\
Ammonium nitrate & $753 \pm 6.00$ \\
Ammonium sulphate & $750 \pm 16.09$ \\
Peptone & $787 \pm 5.57$ \\
Sodium nitrate & $757 \pm 13.89$ \\
Yeast extract & $751 \pm 10.54$ \\
Carbohydrate sources $(0.5 \% \mathrm{w} / \mathrm{w})$ & \\
Fructose & $758 \pm 11.27$ \\
Glucose & $785 \pm 9.64$ \\
Glycerol & $757 \pm 17.62$ \\
Lactose & $758 \pm 14.53$ \\
Xylose & $755 \pm 11.36$ \\
Oil + Nitrogen + Carbohydrate sources & \\
Gingili oil $(1.0 \% \mathrm{w} / \mathrm{w})+$ Peptone $(0.5 \% \mathrm{w} / \mathrm{w})$ & \\
+ Glucose $(0.5 \% \mathrm{w} / \mathrm{w})$ & \\
\hline & \\
\hline
\end{tabular}

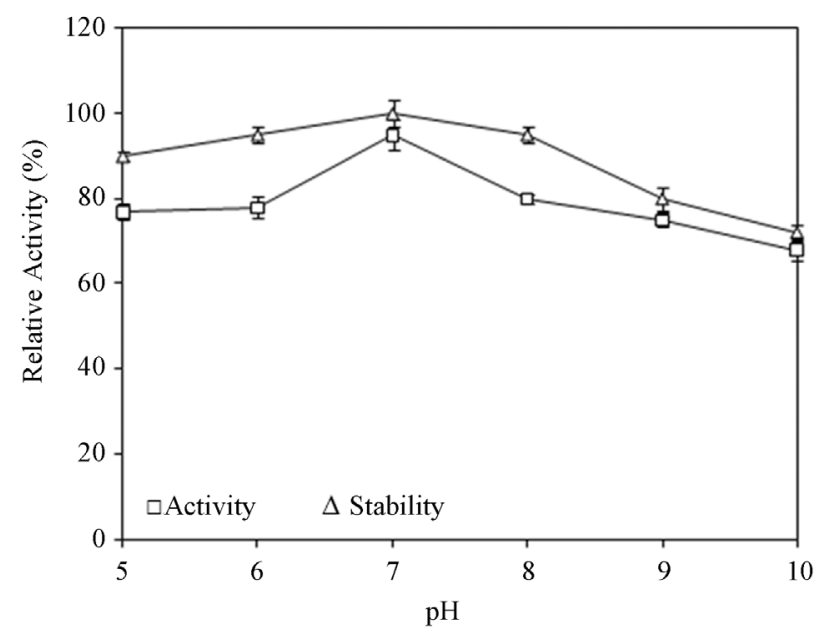

Figure 4 - Effect of $\mathrm{pH}$ on activity and stability of lipase.
7.0-8.5, respectively. The remarkable stability of $A$. tamarii MTCC 5152 lipase at pH 5-8 justifies its potential use in neutral and moderately alkaline conditions.

Lipase activity determined at different temperatures has been presented in Figure 5. The reaction rate increased significantly over the temperature range from $30-50{ }^{\circ} \mathrm{C}$, but then it decreased slightly. The enzyme exhibited maximum activity at $50{ }^{\circ} \mathrm{C}$. The lipase was quite stable at room temperature and the enzyme maintained good stability and was stable up to $50^{\circ} \mathrm{C}$. At $60^{\circ} \mathrm{C}, 90 \%$ activity was retained and above $60{ }^{\circ} \mathrm{C}$ the enzyme gradually loses its activity suggesting that the enzyme is thermostable. Moderately thermostable lipases were also reported from $P$. wortmanii and P. simplicissimum (Costa and Peralta, 1999; Gutarra et al., 2009). These lipases were found to retain $55 \%$ and $90 \%$, of their residual activity at $50{ }^{\circ} \mathrm{C}$.

\section{Effect of lipase concentration and reaction time on fat solubility (FS) of fleshing}

The composition of bovine hides fleshing was determined and found to contain $63 \%$ protein, $14.6 \%$ fat and $8 \%$ ash. The values are in close agreement with the values reported by Kanagaraj et al. (2006). The effect of enzyme concentration on fat solubility is given in Table 2. Maximum fat solubility ( $92 \%$ ) was obtained using 3.0\% enzyme

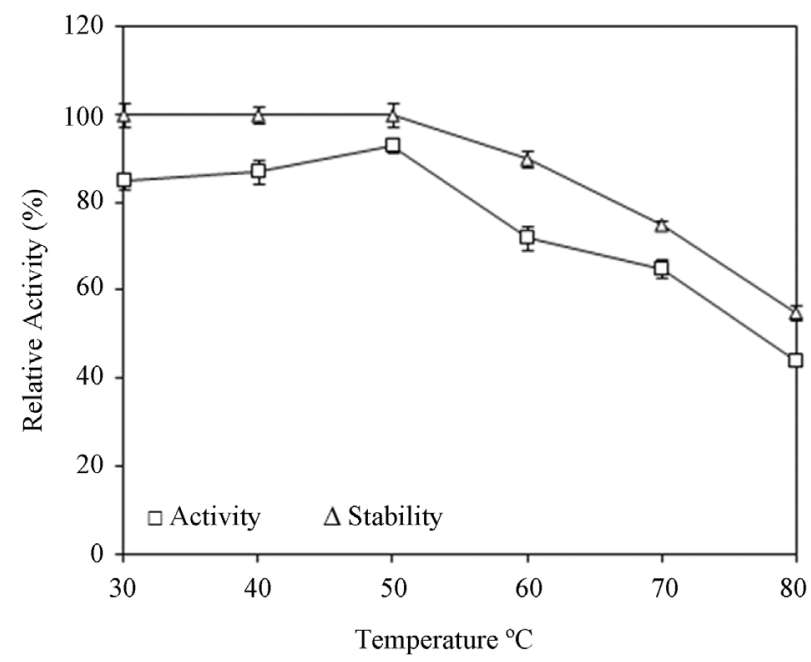

Figure 5 - Effect of temperature on activity and stability of lipase.

Table 2 - Effect of lipase concentration and reaction time on fat solubility (FS) from tannery fleshing.

\begin{tabular}{lccccc}
\hline \multicolumn{5}{c}{ Remarks on fat solubility (FS\%) } \\
\hline Enzyme concentration (v/w) \\
\hline Time (h) & $0.5 \%$ & $1.0 \%$ & $2.0 \%$ & $3.0 \%$ & $4.0 \%$ \\
2 & $30 \pm 1.73$ & $40 \pm 0.50$ & $45 \pm 1.00$ & $50 \pm 2.00$ & $52 \pm 1.00$ \\
4 & $50 \pm 2.65$ & $65 \pm 2.65$ & $70 \pm 1.73$ & $72 \pm 1.00$ & $74 \pm 2.65$ \\
6 & $70 \pm 3.61$ & $80 \pm 1.73$ & $90 \pm 4.00$ & $92 \pm 3.46$ & $92 \pm 3.61$ \\
\hline
\end{tabular}


$(750 \mathrm{u} / \mathrm{mL})$ and $90 \%$ at $2.0 \%$ enzyme concentration in $6 \mathrm{~h}$ of reaction time. These data shows that $92 \%$ of the fat in the fleshing can be removed using lipase from $A$. tamarii MTCC 5152. The fat recovered from the tannery fleshing can be utilized as a potential raw material for the production of an environmentally friendly fuel. The residue is a rich source of protein which can be used as an animal feed particularly as a fish and poultry feed (Rai et al., 2010).

\section{Conclusion}

The production of an extracellularlipase using A.tamarii MTCC 5152 cultured in SSF could be enhanced by modification of medium components with an enzyme yield of $793 \pm 6.56 \mathrm{u} / \mathrm{g}$ dry weight was reached after $120 \mathrm{~h}$ of incubation. This production represented a high level increase of lipolytic activity compared to that obtained in earlier reports. These results are promising because this strain produces lipase in an inexpensive medium. Application of this enzyme on tannery fleshing shows $92 \%$ of fat solubility. The enzymaticaly recovered fat can be used for biodiesel manufacture and the residual protein as a fish or poultry feed.

\section{Acknowledgments}

One of the authors (A. Dayanandan) is thankful to the Council of Scientific and Industrial Research (CSIR), New Delhi for the award of Senior Research Associateship.

\section{References}

Benjamin S, Pandey A (1997) Coconut cake: a potent substrate for production of lipase by Candida rugosa in solid state fermentation. Acta Biotechnol 17:241-251.

Bligh EG, Dyer WJ (1959) A rapid method of total lipid extraction and purification. Can J Biochem Phys 37:911-917.

Colak S, Zengin G, Ozgunay H, Sarykahya H, Sar O, Yuceer L (2005) Utilisation of leather industry prefleshing in biodiesel production. J Soc Leath Tech Ch 100:137-141.

Cordova J, Nemmaoui M, Ismaili-Alaoui M, Morin A, Roussos S, Raimbault M, Benjilali B (1998) Lipase production by solid state fermentation of olive cake and sugar cane bagasse. J Mol Catal B-Enzym 5:75-78.

Costa MAF, Peralta RM (1999) Production of lipase by soil fungi and partial characterization of lipase from a selected strain (Penicillium wortmanii). J Basic Microbiol 39:11-15.

Dayanandan A, Kanagaraj J, Lesley Sounderraj, Govindaraju R, Suseela Rajkumar G (2003) Application of an alkaline protease in leather processing: an ecofriendly approach. J Clean Prod 11:533-536.

Diaz JCM, Rodríguez JA, Roussos S, Cordova J, Abousalham A, Carriere F, Baratti J (2006) Lipase from the thermotolerant fungus Rhizopus homothallicus is more thermostable when produced using solid state fermentation than liquid fermentation procedures. Enzyme Microb Tech 39:1042-1050.

Ghosh PK, Saxena RK, Rani G, Yadav RP, Shebha D (1996) Microbial lipases: production and applications. Sci prog 79:119-157.
Graminha EBN, Gonçalves AZL, Pirota RDPB, Balsalobre MAA, Da Silva R, Gomes E (2008) Enzyme production by solid state fermentation: Application to animal nutrition. Anim Feed Sci Tech 144:1-22.

Gutarra ML, Cavalcanti ED Castilho LR, Freire DM Sant'Anna GL (2005) Lipase production by solid-state fermentation: cultivation conditions and operation of tray and packed-bed bioreactors. Appl Biochem Biotech 121-124:105-16.

Gutarra MLE, Mateus Godoy G, Maugeri F, Rodrigues MI, Denise Freire MG, Leda Castilho R (2009) Production of an acidic and thermostable lipase of the mesophilic fungus Penicillium simplicissimum by solid-state fermentation. Bioresource Technol 100:5249-5254.

Harwood J (1989) The versatility of lipases for industrial uses. Trends Biochem Sci 14:125-126.

Headon DR, Walsh G (1994) The industrial production of enzymes. Biotechnol Adv 12 635-646.

Kamini NR, Fujii T, Kuros T, Iefuji H (2000) Production, purification and characterization of an extracellular lipase from yeast, Cryptococcus sp. S-2. Process Biochem 36:317-324.

Kanagaraj J, Velappan KC, Chandra Babu NK Sadulla S (2006) Solid waste generation in the leather industry and its utilization for a cleaner environment- A Review. J Sci Ind Res 65:541-548.

Kirk O, Borchert TV, Fuglsang CC (2002) Industrial enzyme applications. Curr Opin Biotech 13:345-351.

Kwon DY, Rhee JS (1986) A simple and rapid colorimetric method for determination of free fatty acids for lipase assay. J Am Oil Chem Soc 63:89-92.

Lima VMG, Krieger N, Sarquis MIM, Mitchell DA, Ramos LP, Fontana JD (2003) Effect of nitrogen and carbon sources on lipase production by Penicillium aurantiogriseum. Food Technol Biotech 41:105-110.

Lowry OH, Rosebrough, NJ, Farr AL, Randall RJ (1951) Protein measurement with the folin-phenol reagents. J Biol Chem 193:265-275.

Mahadik DN, Puntambekar US, Bastawde KB, Khire JM, Gokhale DV (2002) Production of acidic lipase by Aspergillus niger in solid state fermentation. Process Biochem 38:715-721.

Mahanta N, Gupta A, Khare SK (2008) Production of protease and lipase by solvent tolerant Pseudomonas aeruginosa PseA in solid-state fermentation using Jatropha curcas seed cake as substrate. Bioresource Technol 99:1729-35.

Mckenzie HA, Wallace HS (1954) Kjeldahl determination of nitrogen: a critical study of digestion conditions. Aust J Chem 7:55-70.

Mladenoska I, Dimitrovski A (2001) Lipase production by Geotrichum candidum-M2. Bull Chem Technol Macedonia 20:39-43.

Ozgunay H, Çolak S, Zengin G, Sari O, Sarikahya H Yuceer L (2007) Performance and emission study of biodiesel from leather industry pre-fleshing. Waste Manage 27 1897-1901.

Pandey A, Soccol CR, Mitchell D (2000) New developments in solid-state fermentation, I: Bioprocesses and products. Process Biochem 35:153-1169.

Rai AK, General T, Bhaskar N, Suresh PV, Sakhare PS, Halami PM, Gowda LR, Mahendrakar NS (2010) Utilization of tannery fleshing: Optimization of conditions for fermenting delimed tannery fleshing using Enterococcus faecium 
HAB01 by response surface methodology. Bioresource Technol 101:1885-91.

Ramachandran S, Singh SK, Larroche C, Soccol CR, Pandey A (2007) Oil cakes and their biotechnological applications, A review. Bioresource Technol 98:2000-2009.

Saxena RK, Davidson WS, Sheoran A, Giri B (2003) Purification and charactrization of an alkaline thermostable lipase from Aspergillus carneus. Process Biochem 39:239-247.

Sugihara A, Shimada Y, Tominaga Y (1988) Purification and characterization of Aspergillus niger lipase. Agric Biol chem 52:1591-92.
Taylor MM, Diefendorf EJ, Thompson CJ Brown EM, Marmer WN, Cabeza LF (1997) Extraction of value added byproducts from the treatment of chromium containing collagenous leather industry waste. J Soc Leath Tech Ch 81:5-13.

Ul-Haq I, Idrees S Rajoka MI (2002) Production of lipases by Rhozopus oligosporous by solid-state fermentation. Process Biochem 37:637-641.

Wiseman A (1995) Introduction to principles. In: Wiseman A, editor. Handbook of enzyme biotechnology. T.J. Press Ltd. Cornwall, UK.

All the content of the journal, except where otherwise noted, is licensed under a Creative Commons License CC BY-NC. 